Research article

\title{
Chemical constituents and antimycobacterial studies of the leaf extracts of Pavetta crassipes K. Schum
}

\author{
Nneka N. Ibekwe ${ }^{1,2} *$, Helena Boshoff ${ }^{3}$, Joaquin Randle ${ }^{4}$, Akinbo A. Adesomoju ${ }^{2}$, \\ Clifton E. Barry III $^{3}$ and Joseph I. Okogun ${ }^{1,4,5}$ \\ ${ }^{1}$ National Institute for Pharmaceutical Research and Development, Abuja, Nigeria \\ ${ }^{2}$ Department of Chemistry, University of Ibadan, Nigeria \\ ${ }^{3}$ Tuberculosis Research Section, LCIM, NIAID, NIH, Building 33, 9000 Rockville Pike, Bethesda, MD 20892, USA \\ ${ }^{4}$ Acorn NMR Inc, 7670 Las Positas Road, Livermore, CA 94551, USA \\ ${ }^{5}$ Emeritus Professor, Department of Chemistry, University of Ibadan, Ibadan, Nigeria
}

*Corresponding Author: nnekaibekwe@yahoo.com

[Accepted: 25 April 2018]

\begin{abstract}
Six known compounds; $\beta$-sitosterol, ursolic acid, methyl chlorogenate, ethyl chlorogenate, rutin and mannitol were isolated from the leaf extracts of Pavetta crassipes (Rubiaceae), a Nigerian medicinal plant used in the indigenous treatment of tuberculosis. Separation and isolation of the compounds were achieved by chromatographic techniques and the structures of isolated compounds were established by spectroscopic and chemical methods. The isolated compounds were screened for antimycobacterial activities against Mycobacterium tuberculosis $\mathrm{H}_{37} \mathrm{Rv}$ employing the green fluorescence protein reporter microplate assay and the broth microdilution method. Ursolic acid, methyl chlorogenate and ethyl chlorogenate were found moderately active in the broth microdilution assay with MICs of 200, 100 and $50 \mu \mathrm{g} / \mathrm{ml}$, respectively while methyl chlorogenate and ethyl chlorogenate were active in the protein reporter microplate assay with MICs of 200 and $100 \mu \mathrm{g} \mathrm{ml} \mathrm{m}^{-1}$, respectively. The presence of antimycobacterial terpenoids and quinate esters in leaves of Pavetta crassipes provides scientific evidence for the ethnomedicinal use of the plant as a traditional anti-tuberculosis remedy.
\end{abstract}

Keywords: Pavetta crassipes - Spectroscopy - Antimycobacterial activity - Broth microdilution assay - Green fluorescent protein reporter microplate assay.

[Cite as: Ibekwe NN, Boshoff H, Randle J, Adesomoju AA, Barry CE III \& Okogun JI (2018) Chemical constituents and antimycobacterial studies of the leaf extracts of Pavetta crassipes K. Schum. Tropical Plant Research 5(1): 88-95]

\section{INTRODUCTION}

Tuberculosis (TB) remains a major global health concern as it is one of the world's deadliest diseases. Approximately one third of the world's population is infected with TB and according to a 2015 World Health Organization (WHO) report, an estimated 10.4 million people fell ill from TB and 1.8 million died from the disease. Africa has the second largest incidence of tuberculosis (26\% of global total) with Nigeria as one of the six countries that accounted for $60 \%$ of new cases (WHO 2016). Current anti-tuberculosis therapy is a regimen of isoniazid, rifampicin and pyrazinamide administered over a period of six months which leads to poor adherence by patients. Inadequate, incomplete, or improperly supervised treatment regimen, poor prescriptions, and co-infection with HIV have caused the emergence of resistant strains of Mycobacterium tuberculosis. Natural products have played and continue to play a significant role in the drug discovery process with tremendous research all across the continents for novel anti-tuberculosis agents. Some excellent review articles on natural products have been published on different classes of compounds; exhibiting antimycobacterial activity (Cantrell et al. 2001, Copp 2003, Okunade et al. 2004, Copp \& Pearce 2007).

African traditional medicine is the oldest, and perhaps the most assorted, of all therapeutic systems and the most common practice across the continent is the use of medicinal plants (Mahomoodally 2013). This practice 
plays an important role in the health care delivery of all African nations and is common especially in the rural areas due to availability, low cost and sometimes the myth associated with these herbs. The rich biodiversity and ethnomedicinal history of the Nigerian flora portend great possibilities in research for novel anti-tubercular compounds. This is however under-explored as only a negligible number of plants used locally in the treatment of characteristic symptoms of TB have been investigated for their antimycobacterial properties.

The leaves of Pavetta crassipes K. Schum (Rubiaceae) are traditionally used in Northern Nigeria for the management of respiratory disorders and TB related symptoms, in ethnobotanical practice. A plant widely distributed in the West African sub-region, P. crassipes is a glabrous shrub to $6 \mathrm{~m}$ high, trunk to $30 \mathrm{~cm}$ girth, of the savanna. It has stout squarish branchlets covered with pale corky bark which splits and falls off; leaves often in threes; flowers greenish-white and fruits black (Burkill 1997). The following pharmacological activities have been reported on the plant; anti-plasmodial/ malarial activity (Sanon et al. 2003), hypotensive activity (Amos et al. 2003), inhibitory effects on gastrointestinal and uterine smooth muscles (Amos et al. 1998) and in vitro antiprotozoal, antimicrobial and antitumor activities (Balde et al. 2010). In our search for novel antimycobacterial agents from Nigerian medicinal plants, the leaves of $P$. crassipes were collected from four different traditional medicine practitioners (TMPs) in Nigeria, as a component of their local herbal recipes for the treatment of tuberculosis (Ibekwe et al. 2014). The ethnobotanical survey revealed P. crassipes to be an interesting plant worth further investigations and this was based on the frequency of plant in the collected recipes from TMPs, potency of the extract based on MIC values, minimal published work on the chemistry of the plant, and novelty of information on plant's use as an anti-TB remedy, hence it was prioritized for further studies. Preliminary studies on the extracts revealed the antimycobacterial potentials of the plant (Ibekwe et al. 2012). There is presently no detailed report on the phytochemistry or antimycobacterial studies of the metabolites of the plant. We report herein, the isolation, structural elucidation of six compounds from the leaf extracts of $P$. crassipes and screening of isolated compounds against M. tuberculosis $\mathrm{H}_{37} \mathrm{Rv}$.

\section{MATERIALS AND METHODS}

\section{General Experimental Procedures}

Melting points were determined with a Barnstead Electrothermal 9100 melting point apparatus and are uncorrected. IR spectra were recorded with a Perkin Elmer Spectrum One FT-IR Spectrophotometer. UV spectra of isolated compounds were run on a Varian Cary 300 Bio UV-Visible Spectrophotometer. HighResolution Mass Spectra (HRMS) were obtained on a q-TOF Waters LCT Premier Mass Spectrometer with electrospray ionization (ESI) or atmospheric pressure ionization (API) source and in the positive or negative mode. ${ }^{1} \mathrm{H}(400 \mathrm{MHz}),{ }^{13} \mathrm{C}$ NMR $(100 \mathrm{MHz})$ and $2 \mathrm{D}$ spectral data were recorded in deuterated $\mathrm{CDCl}_{3}$, DMSO- $d_{6}$, $\mathrm{D}_{2} \mathrm{O}$ or $\mathrm{CD}_{3} \mathrm{OD}$, on a Bruker AMX 400. NMR chemical shifts were expressed in parts per million $(\delta)$ relative to tetramethylsilane (TMS) and the coupling constants were given in Hz. Flash column chromatography were performed on glass columns $(4 \times 150 \mathrm{~cm}, 2.7 \times 70 \mathrm{~cm})$ using silica gel $(230-400 \mu \mathrm{m}$ mesh, Merck, Germany). Preparative TLC were carried out with pre-coated glass backed preparative TLC plates- Kieselgel $60 \mathrm{~F}_{254}(0.5$ $\mathrm{mm}, 20 \times 20 \mathrm{~cm}$; Analtech Inc, USA). Preparative HPLC were performed on a Phenomenex system (Varian Pro Star Model 218 coupled to a Varian fraction collector model 701) using a reverse phase column $250 \times 21.20$ $\mathrm{mm}$ i.d $(5 \mu \mathrm{m}, 100 \mathrm{~A})$. TLC analyses were carried out using silica $60 \mathrm{~F}_{254}$ pre-coated glass backed plates $(0.25$ $\mathrm{mm}, 20 \times 20 \mathrm{~cm}$; Merck, Darmstadt, Germany). Spots were detected on TLC plates under short $(\lambda=254 \mathrm{~nm})$ and long $(\lambda=366 \mathrm{~nm}) \mathrm{UV}$ light and/or visualized by spraying with vanillin-sulphuric acid, followed by charring at $110^{\circ} \mathrm{C}$ for 5 minutes. All chemicals were obtained from commercially available sources and reagents prepared according to standard procedures. The structures of the compounds were confirmed by comparing with reference data from available literature or comparing with data of commercial authentic samples, or by chemical modifications of the isolated compounds.

\section{Plant Material}

The fresh leaves of Pavetta crassipes K. Schum were collected from Suleja, Niger State, Nigeria in July 2009. The plant was identified at the Herbarium Unit of the Department of Medicinal Plant Research and Traditional Medicine, National Institute for Pharmaceutical Research and Development, Abuja (NIPRD). A labeled voucher specimen, NIPRD/H/6241 was deposited in the herbarium of the Institute.

\section{Extraction procedure}

The air dried leaves of $P$. crassipes $(1 \mathrm{~kg})$ were finely pulverised and soaked successively with $\mathrm{n}$-hexane, 
EtOAc and $\mathrm{MeOH}$ at $24 \mathrm{~h}$ intervals. The hexane, EtOAc and $\mathrm{MeOH}$ extracts were evaporated under reduced pressure at $40^{\circ} \mathrm{C}$, to give the crude hexane (green-black syrup, $10.4 \mathrm{~g}$ ), the EtOAc (green powder, $16.8 \mathrm{~g}$ ) and the $\mathrm{MeOH}$ extract (dark brownish sticky solid, $131.7 \mathrm{~g}$ ).

\section{Isolation of components}

The hexane extract $(5.0 \mathrm{~g})$ was subjected to column chromatography with gradient amounts of ethyl acetate in hexane. Fractions were examined by TLC and combined to give 8 major fractions, $\mathrm{PCH}_{1}-\mathrm{PCH}_{8}$. Fraction $\mathrm{PCH}_{5}$ (eluted with $20 \%$ EtOAc in hexane), was similarly re-chromatographed to give 5 sub-fractions, $\mathrm{PCH}_{5.1}-$ $\mathrm{PCH}_{5.5}$. Sub-fraction $\mathrm{PCH}_{5.4}$ (eluted with 10-15\% EtOAc in hexane) was recrystallized from methanol to yield 1 $(22.0 \mathrm{mg})$. Fraction $\mathrm{PCH}_{6}$, eluted with $30 \%$ EtOAc in hexane, was re-chromatographed to obtain 6 subfractions, $\mathrm{PCH}_{6.1}-\mathrm{PCH}_{6.6}$. Crystallization of $\mathrm{PCH}_{6.5}$ (eluted with 30-50\% EtOAc in hexane) from ethanol, yielded $2(34.0 \mathrm{mg})$. The ethyl acetate extract $(9.0 \mathrm{~g})$ was fractionated using column chromatography and eluted with gradient amounts of ethyl acetate in hexane to obtain 14 major fractions, $\mathrm{PCE}_{1}-\mathrm{PCE}_{14}$. Fractions $\mathrm{PCE}_{5}$ and $\mathrm{PCE}_{6}$, eluted with $20 \%$ and $30 \%$ EtOAc in hexane, respectively had similar TLC profiles as fractions $\mathrm{PCH}_{5}$ and $\mathrm{PCH}_{6}$ from the hexane extract. These were re-chromatographed under similar conditions to give 1 (15.0 mg) and $2(102.0 \mathrm{mg})$. Fraction $\mathrm{PCE}_{14}$, eluted with EtOAc and $10 \% \mathrm{MeOH}$ in EtOAc, was chromatographed on a prepHPLC system. The fractions were eluted with a $\mathrm{MeOH}-\mathrm{H}_{2} \mathrm{O}$ gradient in $0.01 \%$ formic acid starting from $\mathrm{MeOH}-\mathrm{H}_{2} \mathrm{O}\{5: 95\}$ solvent A to $\mathrm{MeOH}-\mathrm{H}_{2} \mathrm{O}\{95: 5\}$ solvent $\mathrm{B}$ in 50 minutes with a flow rate of $25 \mathrm{ml} \mathrm{min}^{-1}$. Fractions with similar retention times were combined. Sub-fractions $\mathrm{PCE}_{14.25}-\mathrm{PCE}_{14.30}$ and $\mathrm{PCE}_{14.31}-\mathrm{PCE}_{14-32}$ eluted with $\mathrm{MeOH}-\mathrm{H}_{2} \mathrm{O}\{80: 20\}$ and $\mathrm{MeOH}-\mathrm{H}_{2} \mathrm{O}\{84: 16\}$ were pooled. This procedure was repeated to obtain sufficient amounts of the compounds. Sub-fractions $\mathrm{PCE}_{14 .(25-30)}$ and $\mathrm{PCE}_{14 .(31-32)}$ were further purified using prep TLC developed with $\mathrm{CHCl}_{3}-\mathrm{MeOH}\{9: 1\}$. The separated fractions were suspended in methanol for $30 \mathrm{~min}$, filtered under suction while washing with more methanol. Thereafter, the solvent was evaporated under vacuum, to yield $3(8.0 \mathrm{mg})$ and $4(18.0 \mathrm{mg})$. The methanol extract $(10.0 \mathrm{~g})$ was fractionated using column chromatography, with a gradient elution of ethyl acetate in hexane, and methanol in ethyl acetate to obtain thirteen major fractions, $\mathrm{PCM}_{1}-\mathrm{PCM}_{13}$. Compound $5(56.0 \mathrm{mg})$ precipitated on standing from fraction $\mathrm{PCM}_{10}$ (eluted with $20 \% \mathrm{MeOH}$ in EtOAc) as a yellow powder and was further purified by washing with EtOAc. Fraction $\mathrm{PCM}_{10}$ was further similarly re-chromatographed on a HPLC system to obtain sub-fractions $\mathrm{PCM}_{10.25^{-}}$ $\mathrm{PCM}_{10.30}$, eluted with $\mathrm{MeOH}-\mathrm{H}_{2} \mathrm{O}\{80: 20\}$. Similar fractions were combined and purification of $\mathrm{PCM}_{10 .(25-30)}$ was carried out using prep-TLC developed with $\mathrm{CHCl}_{3}-\mathrm{MeOH}\{9: 1\}$ to give compound 3 (12.0 mg). Fraction $\mathrm{PCM}_{11}$ eluted by $50 \% \mathrm{MeOH}$ in EtOAc, yielded light brown crystals on standing. Further purification by recrystallizing from methanol yielded compound 6 as a white solid $(68.0 \mathrm{mg})$.

\section{Physical and Spectral Data of Isolated Compounds}

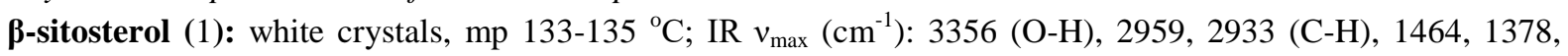
1214, 1060 (C-O); TOF-ES-MS m/z; $397.4\left[\mathrm{M}-\mathrm{H}_{2} \mathrm{O}\right]^{+} ;{ }^{1} \mathrm{H}$ NMR (400 MHz, $\left.\mathrm{CDCl}_{3}\right) \delta_{\mathrm{H}}(\mathrm{ppm}): 5.34(1 \mathrm{H}, \mathrm{d}, \mathrm{H}-$ 6 ), 3.52 (1H, dddd, H-3), 0.82 (3H, d, H-26), 0.80 (3H, d, H-27), 1.00 (3H, s, H-19), 0.91 (3H, d, J = 6 Hz, H21), $0.84(3 \mathrm{H}, \mathrm{t}, J=8.4 \mathrm{~Hz}, \mathrm{H}-29), 0.67(3 \mathrm{H}, \mathrm{s}, \mathrm{H}-18) ;{ }^{13} \mathrm{C} \mathrm{NMR}\left(100 \mathrm{MHz}, \mathrm{CDCl}_{3}\right) \delta_{\mathrm{C}}(\mathrm{ppm}): 140.7(\mathrm{C}-5)$, 121.7 (C-6) ,72.0 (C-3), 56.7 (C-14), 56.0 (C-17), 50.1 (C-9), 45.9 (C-24), 42.3 (C-13), 40.4 (C-12), 39.8 (C-4), 37.2 (C-1), 36.5 ( C-10), 36.1 (C-20), 33.9 (C-22), 31.9 (C-7), 31.6 (C-8), 29.7 (C-2), 29.1 (C-25), 28.2 (C-16), 26.0 (C-23), 24.3 (C-15), 23.0 (C-28), 21.1 (C-11), 19.8 (C-26), 19.3 (C-27), 19.0 (C-19), 18.7 (C-21), 12.0 ( C29), 11.8 (C-18)

Ursolic acid (2): amorphous white solid, mp 284-286 ${ }^{\circ} \mathrm{C}$; IR $v_{\max }\left(\mathrm{cm}^{-1}\right): 3673(\mathrm{O}-\mathrm{H}), 1688(\mathrm{C}=\mathrm{O})$; TOF-ES-MS $m / z ; 457.4[\mathrm{M}+\mathrm{H}]^{+}, 439.4\left[\mathrm{M}-\mathrm{H}_{2} \mathrm{O}\right]{ }^{+} ;{ }^{1} \mathrm{H}$ NMR (400 MHz, DMSO- $\left.d_{6}\right) \delta_{\mathrm{H}}(\mathrm{ppm}): 11.92(1 \mathrm{H}, \mathrm{s}, \mathrm{COOH}-28)$, 5.12 (1H, t, H-12), 4.27 (1H, d, OH-3), 2.99 (1H, m, H-3), 2.09 (1H, d, H-18), 1.03 (3H, s, H-27), 0.90 (3H, d, H-30), 0.89 (3H, s, H-23), 0.86 (3H, s, H-25), 0.81 (3H, d, H-29 ), 0.74 (3H, s, H-26), $0.67(3 \mathrm{H}, \mathrm{s}, \mathrm{H}-24) ;{ }^{13} \mathrm{C}$ NMR (100 MHz, DMSO- $\left.d_{6}\right) \delta_{\mathrm{C}}(\mathrm{ppm}): 178.2$ (C-28), 138.1 (C-13), $124.5(\mathrm{C}-12), 76.8$ (C-3), 54.7 (C-5), 52.3 (C-18), 46.9 (C-9), 46.7 (C-17), 41.6 (C-14), 38.8 (C-8), 38.47 (C-19), 38.40 (C-20), 38.3 (C-4), 38.2 (C-1), 36.5 (C-10), 36.2 (C-22), 32.6 (C-7), 30.1 (C-21), 28.2 (C-23), 27.5 (C-2), 26.9 (C-15), 23.7 (C-16), 23.2 (C27), 22.8 (C-11), 21.0 (C-30), 17.9 (C-6), 16.9 (C-26), 16.8 (C-29), 16.0 (C-24), 15.2 (C-25)

Methyl chlorogenate (3): amorphous yellow solid; (MeOH) $\lambda_{\max }(\mathrm{nm}): 218,330$; TOF-ES-MS, positive ion, $m / z 391.1[\mathrm{M}+\mathrm{Na}]^{+}, 369.1[\mathrm{M}+\mathrm{H}]^{+}$;HRESIMS (positive ion mode) $\mathrm{m} / z$ 369.1191[M $\left.+\mathrm{H}\right]^{+}$(calculated for $\left.\mathrm{C}_{17} \mathrm{H}_{20} \mathrm{O}_{9}+\mathrm{H}, 369.1185\right) ;{ }^{1} \mathrm{H}$ NMR (400 MHz, CD $\left.3 \mathrm{OD}\right) \delta_{\mathrm{H}}(\mathrm{ppm}): 7.52$ (1H, d, J=15.9 Hz, H-7'), 7.03 (1H, d, 
$\left.J=2.0 \mathrm{~Hz}, \mathrm{H}-2^{\prime}\right), 6.94\left(1 \mathrm{H}, \mathrm{dd}, J=2.0 \mathrm{~Hz}, 8.1 \mathrm{~Hz}, \mathrm{H}-6^{\prime}\right), 6.78\left(1 \mathrm{H}, \mathrm{d}, J=8.1 \mathrm{~Hz}, \mathrm{H}-5^{\prime}\right), 6.21(1 \mathrm{H}, \mathrm{d}, J=15.9$ Hz, H-8'), $5.27(1 \mathrm{H}, \mathrm{m}, \mathrm{H}-3), 4.13(1 \mathrm{H}, \mathrm{m}, \mathrm{H}-5), 3.72(1 \mathrm{H}, \mathrm{dd}, J=3.2 \mathrm{~Hz}, 6.8 \mathrm{~Hz}, \mathrm{H}-4), 3.69\left(3 \mathrm{H}, \mathrm{s}, \mathrm{OCH}_{3}, \mathrm{H}-\right.$ 8), 1.98-2.22 (4H, m, H-2, 6); ${ }^{13} \mathrm{C}$ NMR (100 MHz, CD $\left.30 D\right) \delta_{\mathrm{C}}(\mathrm{ppm}): 175.0$ ( C-7), 168.3 (C-9), 149.7 (C-3'), 147.2 (C-7'), 146.9 (C-4'), 127.7 (C-1'), 123.0 (C-6'), 116.5 (C-5'), 115.18 (C-2'), 115.11 (C-7'), 75.9 (C-1), 72.6 (C-4), 72.1 (C-3), 70.4 (C-5), 53.0 (C-1), 38.1 (C-2), 37.8 (C-6)

Ethyl chlorogenate (4): amorphous yellow solid; UV (MeOH) $\lambda_{\max }(\mathrm{nm}): 218$, 330; TOF-ES-MS, positive ion, $\mathrm{m} / \mathrm{z} 405.1[\mathrm{M}+\mathrm{Na}]^{+}, 383.1[\mathrm{M}+\mathrm{H}]^{+}$; HRESIMS (positive ion mode) $\mathrm{m} / \mathrm{z} 383.1344[\mathrm{M}+\mathrm{H}]^{+}$(calculated for $\left.\mathrm{C}_{18} \mathrm{H}_{22} \mathrm{O}_{9}+\mathrm{H}, 383.1342\right) ;{ }^{1} \mathrm{H}$ NMR (400 MHz, DMSO- $\left.d_{6}\right) \delta_{\mathrm{H}}(\mathrm{ppm}): 7.38\left(1 \mathrm{H}, \mathrm{d}, J=15.9 \mathrm{~Hz}, \mathrm{H}-7^{\prime}\right), 7.01(1 \mathrm{H}$, d, $\left.J=2.0 \mathrm{~Hz}, \mathrm{H}-2^{\prime}\right), 6.95\left(1 \mathrm{H}, \mathrm{dd}, J=2.0 \mathrm{~Hz}, 8.1 \mathrm{~Hz}, \mathrm{H}-6^{\prime}\right), 6.76\left(1 \mathrm{H}, \mathrm{d}, J=8.1 \mathrm{~Hz}, \mathrm{H}-5^{\prime}\right), 6.10(1 \mathrm{H}, \mathrm{d}, J=15.9$ Hz, H-8'), $5.01(1 \mathrm{H}, \mathrm{m}, \mathrm{H}-3), 4.01(2 \mathrm{H}, \mathrm{m}, \mathrm{H}-8), 3.86(1 \mathrm{H}, \mathrm{m}, \mathrm{H}-5), 3.56(1 \mathrm{H}, \mathrm{dd}, \mathrm{H}-4), 1.91-2.10(2 \mathrm{H}, \mathrm{m}, \mathrm{H}-2)$, 1.75-2.10 (2H, m, H-6), 1.12 (3H, t, H-9); ${ }^{13} \mathrm{C}$ NMR (100 MHz, CD $\left.{ }_{3} \mathrm{OD}\right) \delta_{\mathrm{C}}(\mathrm{ppm}): 175.0(\mathrm{C}-7), 168.3\left(\mathrm{C}-9^{\prime}\right)$, 149.7 (C-3'), 147.2 (C-7'), 146.9 (C-4'), 127.7 (C-1'), 123.0 (C-6'), 116.5 (C-5'), 115.16 (C-2'), 115.11 (C-7'), 75.8 (C-1), 72.7 (C-4), 72.2 (C-3), 70.4 (C-5), 62.5 ( C-8), 38.0 (C-2), 37.8 (C-6), 14.3 (C-9)

Rutin (5): amorphous yellow solid; UV (MeOH) $\lambda_{\max }(\mathrm{nm}): 257,358$; IR $v_{\max }\left(\mathrm{cm}^{-1}\right): 3337(\mathrm{O}-\mathrm{H}), 2943,2833$ (C-H), 1655 (C=O), 1606 (C=C, aromatic), 1448, 1361, 1306, 1202, 1170; TOF-ES-MS, positive ion, $\mathrm{m} / \mathrm{z} 633.1$ $[\mathrm{M}+\mathrm{Na}]^{+}, 611.1[\mathrm{M}+\mathrm{H}]^{+}, 465.1[\mathrm{M}+\mathrm{H}-146]^{+}, 449.1[\mathrm{M}+\mathrm{H}-162]^{+}$; HRESIMS (positive ion mode) $\mathrm{m} / \mathrm{z}$ $611.1599[\mathrm{M}+\mathrm{H}]^{+}$(calculated for $\left.\mathrm{C}_{27} \mathrm{H}_{30} \mathrm{O}_{16}+\mathrm{H}, 611.1611\right) ;{ }^{1} \mathrm{H}$ NMR $\left(400 \mathrm{MHz}, \mathrm{CD}_{3} \mathrm{OD}\right): \delta_{\mathrm{H}}(\mathrm{ppm}): 7.66(\mathrm{~d}$, $\left.J=2.0 \mathrm{~Hz}, \mathrm{H}-2^{\prime}\right), 7.62$ (dd, $\left.J=2.0,8.0 \mathrm{~Hz}, \mathrm{H}-6^{\prime}\right), 6.85$ (d, $J=8.0 \mathrm{~Hz}, \mathrm{H}-5$ '), 6.39 (d, $\left.J=2.0 \mathrm{~Hz}, \mathrm{H}-8\right), 6.20$ (d, $J$ $=2.0 \mathrm{~Hz}, \mathrm{H}-6)$; glucosyl protons: $5.11\left(1 \mathrm{H}, \mathrm{d}, J=7.6 \mathrm{~Hz}, \mathrm{H}-1^{\prime}\right), 3.80\left(1 \mathrm{H}, \mathrm{dd}, \mathrm{H}-6^{\mathrm{a}}\right), 3.44(1 \mathrm{H}, \mathrm{t}, J=3.2 \mathrm{~Hz}, \mathrm{H}-$ 2"), $3.38\left(1 \mathrm{H}, \mathrm{dd}, \mathrm{H}-6^{\mathrm{b}^{\prime}}\right)$; rhamnosyl protons: $4.51(1 \mathrm{H}, \mathrm{d}, J=1.6 \mathrm{~Hz}, \mathrm{H}-1 "), 1.12(3 \mathrm{H}, \mathrm{d}, J=6 \mathrm{~Hz}, \mathrm{H}-6 ")$, other glycosidic protons; 3.24 - 3.49 (multiplet); ${ }^{13} \mathrm{C}$ NMR (100 MHz, $\left.\mathrm{CD}_{3} \mathrm{OD}\right) \delta_{\mathrm{C}}(\mathrm{ppm})$ : aglycone: 179.4 (C-4), 166.0 (C-7), 162.9 (C-5), 159.3 (C-2), 158.5 (C-9), 149.8 (C-4'), 145.8 (C-3'), 135.6 (C-3), 123.5 (C-6'), 123.1 (C-1'), 117.6 (C-2'), 116.0 (C-5'), 105.6 (C-10), 99.9 (C-6), 94.8 (C-8), glucose and rhamnose; 104.7 (C-1"), 102.4 (C-1"'), 75.7 (C-2"), 68.5 (C-6"), 17.8 (C-6"'), other glycosidic carbons (69.7, 71.3, 72.1, 72.2, 73.9, 77.2 and 78.1)

Mannitol (6): white solid, mp 154-157 ${ }^{\circ} \mathrm{C}$; IR $v_{\max }\left(\mathrm{cm}^{-1}\right): 3329$ (O-H), 2989 (C-H), 2108, 1637, 1394, 1250, 1066 (C-O); TOF-AP-MS, positive ion, $m / z 183.1[\mathrm{M}+1]^{+}, 165.1\left[\mathrm{M}+1-\mathrm{H}_{2} \mathrm{O}\right]^{+}, 147.1\left[165.1-\mathrm{H}_{2} \mathrm{O}\right]^{+}, 129.1$ [147.1 $\left.-\mathrm{H}_{2} \mathrm{O}\right]^{+}, 111.1\left[129.1-\mathrm{H}_{2} \mathrm{O}\right]^{+}$, HRESIMS (positive ion mode) $\mathrm{m} / z 183.0872[\mathrm{M}+\mathrm{H}]^{+}$(calculated for $\left.\mathrm{C}_{6} \mathrm{H}_{14} \mathrm{O}_{6}+\mathrm{H}, 183.0868\right) ;{ }^{1} \mathrm{H}$ NMR $\left(400 \mathrm{MHz}, \mathrm{D}_{2} \mathrm{O}\right) \delta_{\mathrm{H}}(\mathrm{ppm}): 3.75(2 \mathrm{H}, \mathrm{dd}, J=2.4,11.7 \mathrm{~Hz}, \mathrm{H}-1,6), 3.68(2 \mathrm{H}$, $\mathrm{d}, J=8.6 \mathrm{~Hz}, \mathrm{H}-3,4), 3.64(2 \mathrm{H}, \mathrm{m}, \mathrm{H}-2,5), 3.56(2 \mathrm{H}, \mathrm{dd}, J=6,11.7 \mathrm{~Hz}, \mathrm{H}-1,6) ;{ }^{13} \mathrm{C}$ NMR $(100 \mathrm{MHz}$, $\left.\mathrm{CD}_{3} \mathrm{OD}\right) \delta_{\mathrm{C}}(\mathrm{ppm}): 70.8(\mathrm{C}-2,5), 69.2(\mathrm{C}-3,4)$ and $63.2(\mathrm{C}-1,6)$

Acid hydrolysis of rutin (5): Compound $5(10 \mathrm{mg})$ was dissolved in $1 \mathrm{ml}$ of methanol with concentrated $\mathrm{HCl}$ $(0.5 \mathrm{ml})$ and the solution was kept under reflux for $5 \mathrm{~h}$ at $70^{\circ} \mathrm{C}$. After removal of $\mathrm{MeOH}$ by rotary evaporation, the residue was partitioned between n-butanol and $\mathrm{H}_{2} \mathrm{O}$. The butanol (lower) layer was removed, dried over anhydrous $\mathrm{Na}_{2} \mathrm{CO}_{3}$ and concentrated under reduced pressure, to afford $3 \mathrm{mg}$ of $\mathbf{5 a}$.

Quercetin (5a): amorphous yellow solid, mp 297-300 ${ }^{\circ} \mathrm{C}$; UV (MeOH) $\lambda_{\max }(\mathrm{nm}): 257$, 358; TOF-MS-API, positive ion, $\mathrm{m} / z 303.1[\mathrm{M}+1]^{+} ;{ }^{13} \mathrm{C}$ NMR $\left(100 \mathrm{MHz}, \mathrm{CD}_{3} \mathrm{OD}\right) \delta_{\mathrm{C}}(\mathrm{ppm}): 176.5(\mathrm{C}-4), 166.0(\mathrm{C}-7), 161.0(\mathrm{C}-$ 5), 156.7 (C-9), 148.1 (C-4'), 147.5 (C-2), 145.7 (C-3'), 136.5 (C-3), 123.0 (C-1'), 121.0 (C-6'), 116.5 (C-2'), 116.0 (C-5'), 104.0 (C-10), 99.5 (C-6), 94.5 (C-8)

\section{Antimycobacterial assay}

Following the extractions, chromatographic separations and purification of compounds from the leaves of $P$. crassipes, compounds were screened against Mycobacterium tuberculosis and bioassays were conducted on drug sensitive $\mathrm{H}_{37} \mathrm{Rv}$ ATCC 27294. M. tuberculosis was grown in 7H9-medium (which consisted of Middlebrook $7 \mathrm{H} 9$ broth base supplemented with $0.5 \%$ (w/v) Albumin, $0.2 \%(\mathrm{w} / \mathrm{v})$ glucose, $0.2 \%(\mathrm{v} / \mathrm{v})$ glycerol, $0.08 \%(\mathrm{w} / \mathrm{v}) \mathrm{NaCl}$ and $0.05 \%$ (v/v) Tween 80), to an optical density (OD) $650 \mathrm{~nm}$ of $0.2-0.3$ after which cells were diluted 1000-fold in 7H9-medium. The Green Fluorescent Protein Reporter Microplate Assay (GFPMA; Collins et al. 1998) and a modified Broth Microdilution Method (BMM; Coban et al. 2004) were employed in the assessment of antimycobacterial activity. Assays of compounds were carried out utilizing a constitutive Green Fluorescence Protein (GFP) expression vector direct readout of fluorescence (with excitation at $485 \mathrm{~nm}$ and emission at $509 \mathrm{~nm}$ ) as a measure of bacterial growth. Mycobacterium tuberculosis $\mathrm{H}_{37} \mathrm{Rv}$ with a constitutive GFP plasmid was used as a test strain. Compounds were prepared in 100\% DMSO at an initial stock 
concentration of $10 \mathrm{mg} \mathrm{mL}^{-1}$ and serial dilutions of the compounds were prepared in the same solvent and added to the wells of a black clear-bottom 384-well microtiter plate (in order to minimize background fluorescence) at $2 \mu \mathrm{L}$ volume compound per well. Forty eight (48) $\mu \mathrm{L}$ of $\mathrm{H}_{37} \mathrm{Rv}$-GFP bacterial suspension was added to the different concentrations of the compound across the wells resulting in a final volume of $50 \mu \mathrm{L}$. Plates were then incubated at $37^{\circ} \mathrm{C}$ for 5 days. Mycobacterial growth was determined by measuring GFP fluorescent intensity at $509 \mathrm{~nm}$ using a multilabel reader. The increase in fluorescence indicated growth of the GFP-expressing strain whereas a lack of increase of fluorescence readout or even a decrease in fluorescence relative to the day 0 fluorescence value, indicated growth inhibition. Isoniazid was used as positive control (100\% growth) and DMSO as negative control ( $0 \%$ growth). All the bioassay experiments were done in duplicates and assay results were reported in the form of MIC values. For the broth microdilution assay, pure compounds for biological assay were prepared at a concentration of $10 \mathrm{mg} \mathrm{ml}^{-1}$ in $100 \%$ DMSO and $40 \mu \mathrm{l}$ of the stock solution was taken into $460 \mu \mathrm{L} 7 \mathrm{H} 9$-medium. Serial two fold dilutions were made in the broth medium at $50 \mu \mathrm{L}$ per well in clear 96-well round-bottom microtitre plates after which an equal volume of diluted M. tuberculosis $\mathrm{H}_{37} \mathrm{Rv}$ was added at 10,000 cells per well with the final top concentration of DMSO at $2 \%$ and incubated at $37^{\circ} \mathrm{C}$ in a humid atmosphere for 7-10 days. Growth was visually scored using an enlarging inverted mirror. Isoniazid was used as positive control. The minimum inhibitory concentration (MIC) was taken as the lowest concentration that completely inhibited all visible growth.

\section{RESULTS AND DISCUSSION}

Repeated column chromatography (silica gel), prep HPLC and prep TLC of the extracts of the leaves of Pavetta crassipes yielded compounds 1-6 (Fig. 1). The chemical structures of the isolated compounds were established using spectral data obtained from UV, IR, MS and ${ }^{1} \mathrm{H}$ and ${ }^{13} \mathrm{C}$ NMR spectra in conjunction with 2D experiments, COSY, HSQC and HMBC. These were compared with published literature and in one of the cases, with the authentic commercial specimen (Compound 2). Chemical modification and spectral analysis of reaction product were useful in establishing the structure of Compound 5.

The compounds isolated from the leaves of $P$. crassipes were identified as $\beta$-sitosterol $\mathrm{C}_{29} \mathrm{H}_{50} \mathrm{O}$ (1) (Lee et al. 2003), ursolic acid (2) $\mathrm{C}_{30} \mathrm{H}_{48} \mathrm{O}_{3}$ (Seebacher et al. 2003), methyl chlorogenate $\mathrm{C}_{17} \mathrm{H}_{20} \mathrm{O}_{9}$ (3) (Lee et al. 2010), ethyl chlorogenate $\mathrm{C}_{18} \mathrm{H}_{22} \mathrm{O}_{9}$ (4) (Lee et al. 2010), rutin $\mathrm{C}_{27} \mathrm{H}_{30} \mathrm{O}_{16}$ (5) (Lallemand \& Duteil 1977, Bello et al. 2011) and mannitol $\mathrm{C}_{6} \mathrm{H}_{12} \mathrm{O}_{6}(\mathbf{6})$ (Hagiwara et al. 2005). Quercetin $\mathrm{C}_{15} \mathrm{H}_{10} \mathrm{O}_{7}(\mathbf{5 a})$, the hydrolyzed product of rutin, was also identified (Lallemand \& Duteil 1977). The structures of the compounds are as shown in figure 1 and the spectroscopic and physical data are presented in the section on Material and Methods.

All compounds were screened for their inhibitory activity on the growth of Mycobacterium tuberculosis $\mathrm{H}_{37} \mathrm{Rv}$, with final concentrations of $200 \mu \mathrm{g} \mathrm{mL}^{-1}$ (GFPMA) and $400 \mu \mathrm{g} \mathrm{mL}^{-1}$ (BMM) and the results are presented in table 1. The GFPMA assay revealed only the quinate esters; ethyl chlorogenate (4) and methyl chlorogenate (3) with activities against M. tuberculsis $\mathrm{H}_{37} \mathrm{Rv}$ at 100 and $200 \mu \mathrm{g} \mathrm{ml}^{-1}$, respectively, while the BMM assay showed ethyl chlorogenate (4) methyl chlorogenate (3) and ursolic acid (2), with activities with MIC of 50, 100 and $200 \mu \mathrm{g} / \mathrm{ml}$, respectively. Interestingly, the bioactive chlorogenate esters are structurally similar, but for the length of the alkyl substituent, with ethyl chlorogenate being less polar. The differences in biological activities of the chlorogenate esters may be owed to their differences in polarity as less polar compounds have been shown to inhibit the growth of M. tuberculosis due to the easier permeability of the cell wall of the bacterium which is lipophilic in nature (Ducati et al. 2006). The antimycobacterial activities of ethyl chlorogenate (4) and methyl chlorogenate (3) have not been reported hitherto. Ursolic acid (2) which is a pentacyclic triterpene, and its analogue, 24-hydoxyursolic acid have previously been reported as antimycobacterial agents from Valeriana laxiflora (Gu et al. 2004) and Leyssera gnaphaloides (Bamuamba et al. 2008). Some pentacyclic tritepenes with substituents in C-3 and C-17, such as oleanolic acid, oleanonic acid, and 3-epioleanolic acid inhibited the growth of M. tuberculosis $\mathrm{H}_{37} \mathrm{Rv}$ with MIC values of 50, 16, and 16 $\mu \mathrm{g} / \mathrm{mL}$, respectively (Caldwell et al. 2000). It has been reported that the presence of hydroxyl or keto groups in A or B rings, and a carboxylic group in $\mathrm{D} / \mathrm{E}$ rings, gave the molecule a moderate antimycobacterial activity (Wächter et al. 1999, Caldwell et al. 2000). These authors also suggested that the mechanism of action of such triterpenoids depended on the lipophilicity of the compounds that allowed a rapid penetration across the lipidrich mycobacterial cell wall. In their review article, Ducati et al. (2006) also stated that lipophilic molecules should be able to easily cross the mycobacterium membrane, dissolving in the hydrocarbon interior of the lipid bilayer, though factors such as low fluidity of the mycolic acid leaflet and the bilayer's uncommon thickness www.tropicalplantresearch.com 
may result in reduction of this process.

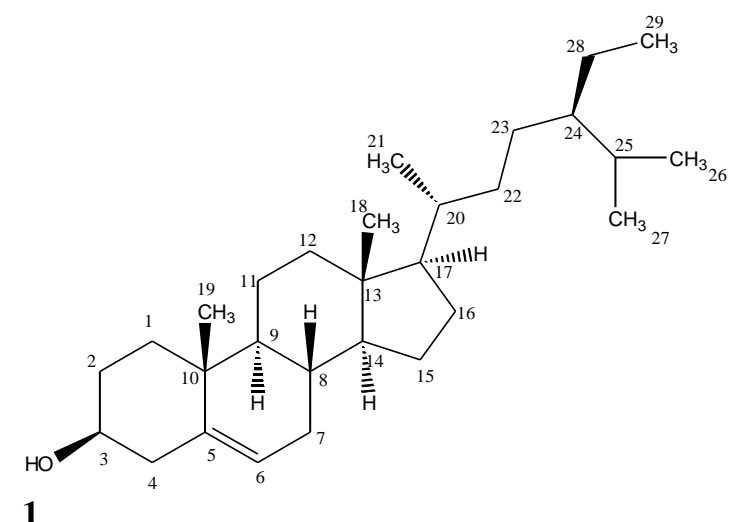<smiles>O=C(/C=C/c1ccc(O)c(O)c1)OC1CC(O)(C(=O)O)CC(O)C1O</smiles>

$3 \mathrm{R}=\mathrm{CH}_{3}$

$4 \mathrm{R}=\mathrm{CH}_{2} \mathrm{CH}_{3}$

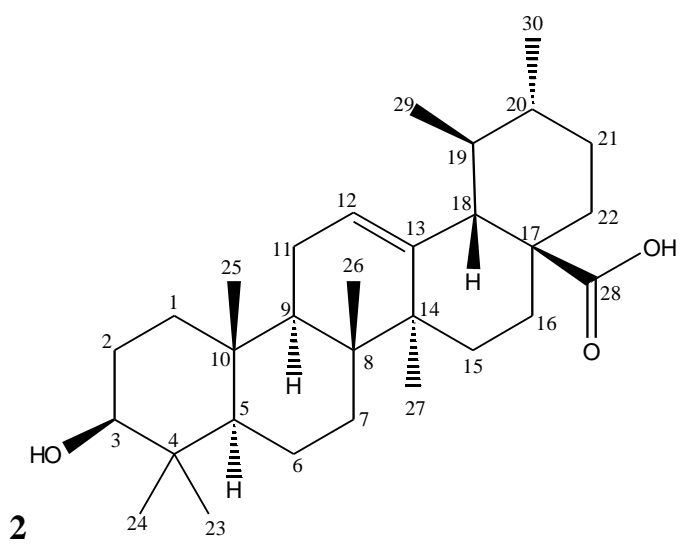

2

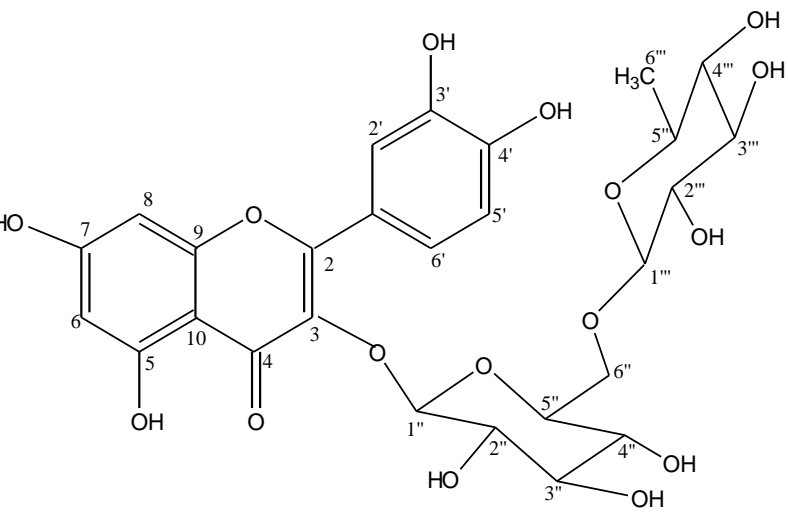

5<smiles>O=c1c(O)c(-c2ccc(O)c(O)c2)oc2cc(O)cc(O)c12</smiles><smiles>OC[C@@H](O)[C@H](O)[C@H](O)[C@H](O)CO</smiles>

Figure 1. Structures of compounds (1-6) from the leaves of Pavetta crassipes.

Table 1 Antimycobacterial activity of compounds against Mycobacterium tuberculosis $\mathrm{H}_{37} \mathrm{Rv}$.

\begin{tabular}{lll}
\hline Compound & GFPMA & BMM \\
& MIC in $\boldsymbol{\mu} \mathbf{g} \mathbf{~ m L}^{-\mathbf{1}}$ & MIC in $\boldsymbol{\mu g} \mathbf{~ m L}^{-\mathbf{1}}$ \\
\hline $\mathbf{1}$ & NA* & NA \\
$\mathbf{2}$ & NA & 200 \\
$\mathbf{3}$ & 200 & 100 \\
$\mathbf{4}$ & 100 & 50 \\
$\mathbf{5}$ & NA & NA \\
$\mathbf{5 a}$ & NA & NA \\
$\mathbf{6}$ & NA & NA \\
\hline
\end{tabular}

Note: $\mathrm{NA}=$ not active at the concentrations tested. The MIC of isoniazid, the reference compound for the antimycobacterial assay was $0.2 \mu \mathrm{M}$

Comparing the MICs of the two bioassay methods in the antimycobacterial assay, BMM shows more sensitivity than GFPMA. However, since the intrinsically fluorescent nature of GFP precludes the need for a substrate, GFPMA offers greater simplicity and also has enhanced biosafety since the microplate need not be reopened following inoculation (Collins et al. 1998). 
The phytochemistry of $P$. crassipes is also important as a chemotaxonomic study, as some of the isolated compounds may be useful as markers of the Rubiaceae family. Compounds such as triterpene acids, steroids, chlorogenic acid derivatives and flavonoids have been reported from other species of the Rubiaceae family (Martins \& Nunez 2015).

\section{CONCLUSIONS}

This is the first detailed report of the phytochemistry of the leaves of Pavetta crassipes, with rutin as the only compound previously isolated (Bello et al. 2011). An extensive literature search carried out did not reveal much information on the phytochemistry of plants in the Pavetta genus. In vitro screening against Mycobacterium tuberculosis employing the microbroth dilution and the green fluorescent protein microplate assay techniques showed that the antituberculosis activities of $P$. crassipes leave were attributed to a ursane type triterpene acid, ursolic acid and two chlorogenate esters, methyl chlorogenate and ethyl chlorogenate. This is the first report of the antimycobacterial activities of these compounds from this plant and more interestingly the first report of chlorogenate esters as antimycobacterial agents. This group of phenolics may represent promising antimycobacterial agents and should be investigated further as potential leads in the drug discovery of antituberculosis agents. The antimycobacterial activities of the leaves of $P$. crassipes are relevant and it would be interesting to explore the potentials of the bioactive compounds; ursolic acid and the chlorogenate esters as drug templates by carrying out structural activity relationship (SAR) studies to synthesize new derivatives which may be highly specific to treat the disease. This study provides, at least in part, some scientific basis and a biological explanation for the ethnomedicinal use of $P$. crassipes as a traditional antituberculosis remedy in Nigeria, through a combination of indigenous knowledge and natural products chemistry.

\section{ACKNOWLEDGEMENTS}

N. N. Ibekwe wishes to sincerely thank the Division of Acquired Immunodeficiency Syndrome (DAIDS), National Institute of Allergy and Infectious Diseases (NIAID), National Institute of Health, Maryland for the doctoral fellowship. Funding for this program was provided (in part) by the Division of Intramural Research of the NIAID (project no- A1000693-22), National Institutes of Health (NIH). She also acknowledges Oak Ridge Associated Universities, Tennessee, for administering the program and the National Institute for Pharmaceutical Research and Development (NIPRD), Abuja for support. The authors thank Dogonyaro Bege and Matthew Tsado, for the instrument and information technology support, respectively. They express their gratitude to the four TMPs who provided the plant for our ethnobotanical study; Isa Mai Maigani and Rabiu Sule from Zaria in Kaduna state and Azijah Oyhu and Haruna Mary from Jos in Plateau state. They also thank Muazzam Ibrahim of NIPRD, for his assistance with collection of the plant, and Dr Jemilat Ibrahim, for the botanical identification of the plant.

\section{REFERENCES}

Amos S, Akah PA, Binda L, Enwerem NM, Ogundaini A, Wambebe C, Hussaini IM \& Gamaniel KS (2003) Hypotensive activity of the ethanol extract of Pavetta crassipes leaves. Biological and Pharmaceutical Bulletin 26: 1674-1680.

Amos S, Okwuasaba FK, Gamaniel K, Akah P \& Wambebe C (1998) Inhibitory effects of the aqueous extract of Pavetta crassipes leaves on gastrointestinal and uterine smooth muscle preparations isolated from rabbits, guinea pigs and rats. Journal of Ethnopharmacology 61: 209-213.

Balde ES, Megalizzi V, Traore MS, Cos P, Maes L, Decaestecker C, Pieters L \& Balde AM (2010) In vitro antiprotozoal, antimicrobial and antitumor activity of Pavetta crassipes K. Schum leaf extracts. Journal of Ethnopharmacology 130: 529-535.

Bamuamba K, Gammon DW, Meyers P, Dijoux-Franca MG \& Scott G (2008) Anti-mycobacterial activity of five plant species used as traditional medicines in the Western Cape Province (South Africa). Journal of Ethnopharmacology 117: 385-390.

Bello IA, Ndukwe GI, Audu OT \& Habila JD (2011) A bioactive flavonoid from Pavetta crassipes K. Schum. Organic and Medicinal Chemistry Letters 1: 14. [doi: 10.1186/2191-2858-1-14]

Burkill HM (1997) The useful plants of West Tropical Africa. Royal Botanic Gardens, Kew, pp. 588.

Caldwell CG, Franzblau SG, Suarez E \& Timmermann BN (2000) Oleanane triterpenes from Junellia tridens. Journal of Natural Products 63: 1611-1614. 
Cantrell CL, Franzblau SG \& Fischer NH (2001) Antimycobacterial plant terpenoids. Planta Medica 67: 685694.

Coban AY, Birinci A, Ekinci B \& Durupinar B (2004) Drug susceptibility testing of Mycobacterium tuberculosis by the broth microdilution method with 7H9 broth. Memorias de Instituto Oswaldo Cruz 99: 111-113.

Collins LA, Terreto MN, Franzblau SG (1998) Green fluorescent protein reporter microplate assay for highthroughput screening of compounds against Mycobacterium tuberculosis. Antimicrobial Agents and Chemotherapy 42: 344-347.

Copp BR (2003) Antimycobacterial natural products. Natural Product Reports 20: 535-557.

Copp BR, Norrie Pearce A (2007) Natural product growth inhibitors of Mycobacterium tuberculosis. Natural Product Reports 24: 278-297.

Ducati RG, Ruffino-Netto A, Basso LA \& Santos DS (2006) The resumption of consumption - A review on tuberculosis. Memorias de Instituto Oswaldo Cruz 101: 697-714.

Gu JQ, Wang Y, Franzblau SG, Montenegro G, Yang D \& Timmermann BN (2004) Antitubercular constituents of Valeriana laxiflora. Planta Medica 70: 509-514.

Hagiwara S, Takahashi M, Shen Y, Kaihou S, Tomiyama T, Yazawa M, Tamai Y, Sin Y, Kazusaka A \& Terazawa M (2005) A phytochemical in the edible Tamogi-take mushroom (Pleurotus cornucopiae), DMannitol, inhibits ACE activity and lowers the blood pressure of spontaneously hypertensive rats. Bioscience Biotechnology and Biochemistry 69: 1603-1605.

Ibekwe NN, Nvau JB, Oladosu PO, Usman AM, Ibrahim K, Boshoff HI, Dowd CS, Orisadipe AT, Aiyelaagbe O, Adesomoju AA, Barry III CE \& Okogun JI (2014) Some Nigerian anti-tuberculosis ethnomedicines: A preliminary efficacy assessment. Journal of Ethnopharmacology 155: 524-532.

Ibekwe NN, Orishadipe AT, Boshoff H, Adesomoju AA, Okogun JI \& Barry CE (2012) In vitro antimycobacterial studies on the leaf extracts and fractions of Pavetta crassipes K.Schum. African Journal of Pure and Applied Chemistry 6: 55-58.

Lallemand JY \& Duteil M (1977). ${ }^{13}$ C NMR spectra of quercetin and rutin. Organic Magnetic Resonance 9: 179-180.

Lee EJ, Kim JS, Kim HP, Lee J-H \& Kang SS (2010) Phenolic constituents from the flower buds of Lonicera japonica and their 5-lipoxygenase inhibitory activities. Food Chemistry 120: 134-139.

Lee S, Kim KS, Shim SH, Park YM \& Kim B-K (2003) Constituents from the non-polar fraction of Artemisia apiacea. Archives of Pharmacetical Research 26(11): 902-905.

Mahomoodally MF (2013) Traditional Medicines in Africa: An Appraisal of Ten Potent African Medicinal Plants. Evidence Based Complimentary and Alternative Medicine 2013: Article ID 617459. [doi:10.1155/2013/617459]

Martins D \& Nunez CV (2015) Secondary metabolites from rubiaceae species. Molecules 20: 13422-13495.

Okunade AL, Elvin-Lewis MP \& Lewis WH (2004) Natural antimycobacterial metabolites: current status. Phytochemistry 65: 1017-1032.

Sanon S, Ollivier E, Azas N, Mahiou V, Gasquet M, Ouattara CT, Nebie I, Traore AS, Esposito F, Balansard G, Timon-David P \& Fumoux F (2003) Ethnobotanical survey and in vitro antiplasmodial activity of plants used in traditional medicine in Burkina Faso. Journal of Ethnopharmacology 86: 143-147.

Seebacher W, Simic N, Weis R, Saf R \& Kunert O (2003) Complete assignments of ${ }^{1} \mathrm{H}$ and ${ }^{13} \mathrm{C}$ NMR resonances of oleanolic acid, 18 $\alpha$-oleanolic acid, ursolic acid and their 11-oxo derivatives. Magnetic Resonance Chemistry 41: 636-638.

Wächter GA, Valcic S, Flagg ML, Franzblau SG, Montenegro G, Suarez E \& Timmermann BN (1999) Antitubercular activity of pentacyclic triterpenoids from plants of Argentina and Chile. Phytomedicine 6: 341-345.

WHO (2016) Global tuberculosis report. World Health Organization, Geneva. Available from: http://apps.who.int/iris/bitstreeam/10665/250441/1/9789241565494-eng.pdf. (accessed: 16 Nov. 2017). 